\title{
A Selective Role for Lmo4 in Cue-Reward Learning
}

\author{
@Rajani Maiya, ${ }^{1,2}$ Regina A. Mangieri, ${ }^{1}$ Richard A. Morrisett, ${ }^{1}$ Ulrike Heberlein, ${ }^{2}$ and ${ }^{-R o b e r t} 0$. Messing $^{1,2}$ \\ ${ }^{1}$ Division of Pharmacology and Toxicology, College of Pharmacy, University of Texas at Austin, Austin, Texas 78712, and ${ }^{2}$ Ernest Gallo Clinic and Research \\ Center, Emeryville, California 94608
}

The ability to use environmental cues to predict rewarding events is essential to survival. The basolateral amygdala (BLA) plays a central role in such forms of associative learning. Aberrant cue-reward learning is thought to underlie many psychopathologies, including addiction, so understanding the underlying molecular mechanisms can inform strategies for intervention. The transcriptional regulator LIM-only 4 (LMO4) is highly expressed in pyramidal neurons of the BLA, where it plays an important role in fear learning. Because the BLA also contributes to cue-reward learning, we investigated the role of BLA LMO4 in this process using Lmo4-deficient mice and RNA interference. Lmo4-deficient mice showed a selective deficit in conditioned reinforcement. Knockdown of LMO4 in the BLA, but not in the nucleus accumbens, recapitulated this deficit in wild-type mice. Molecular and electrophysiological studies identified a deficit in dopamine D2 receptor signaling in the BLA of Lmo4-deficient mice. These results reveal a novel, LMO4-dependent transcriptional program within the BLA that is essential to cue-reward learning.

Key words: basolateral amygdala; conditioned reinforcement; motivation; reward; transcription

\section{Introduction}

The formation of conditioned associations between environmental cues and appetitive and aversive events is important for survival. The BLA plays a central role in such forms of associative learning and is important for the processing of emotions of both positive and negative valence (Everitt et al., 1999; Holland and Gallagher, 1999; Baxter and Murray, 2002). Studies of fear conditioning, in which animals learn to associate a previously neutral conditioned stimulus (CS) with an aversive unconditioned stimulus (US), have provided strong evidence for the role of the BLA in emotional learning (LeDoux, 2000). However, the BLA is also implicated in the processing of positive emotions. When a CS is paired with an appetitive US, it acquires motivational value. This acquired value of the CS is displayed in several ways. Cues paired with a reward can elicit approach when presented alone, increase responding to the primary reinforcer, and also serve as conditioned reinforcers supporting the learning of novel instrumental behaviors (Everitt et al., 1999; Holland and Gallagher, 1999; Baxter and Murray, 2002). These properties of reward-paired cues arise from Pavlovian conditioning and can be dissociated in terms of their neuroanatomical correlates. Rats with BLA lesions display deficits in conditioned reinforcement and responding

Received May 4, 2015; accepted May 27, 2015.

Author contributions: R.M., R.A. Mangieri, R.A. Morrisett, U.H., and R.O.M. designed research; R.M. and R.A. Mangieri performed research; R.M., R.A. Mangieri, and R.A. Morrisett analyzed data; R.M., R.A. Mangieri, R.A. Morrisett, and R.O.M. wrote the paper.

This work was supported by State of California funds (U.H. and R.O.M.), University of Texas at Austin startup funds (R.O.M.), and National Institutes of Health Grant R01AA16651 (R.A.M). We thank the members of the Heberlein and Messing laboratories for their comments on the manuscript.

The authors declare no competing financial interests.

Correspondence should be addressed to Rajani Maiya, PhD, College of Pharmacy, C0875, 107 W. Dean Keeton,

BME6.116, University of Texas, Austin, TX 78712. E-mail: Rajani.Maiya@austin.utexas.edu.

U. Heberlein's present address: HHMI, Janelia Research Campus, 9700 Helix Drive, Ashburn, VA 20147.

DOI:10.1523/JNEUROSCI.1740-15.2015

Copyright $\odot 2015$ the authors $\quad 0270-6474 / 15 / 359638-10 \$ 15.00 / 0$ under second-order schedules of reinforcement, suggesting a critical role for the BLA in attributing motivational properties to reward-paired cues (Cador et al., 1989; Hatfield et al., 1996; Everitt et al., 1999; Baxter and Murray, 2002; Di Ciano and Everitt, 2004). Although much is known about neural structures responsible for imbuing reward-paired cues with incentive properties, the underlying molecular mechanisms remain largely unexplored.

Recent evidence implicates LIM-only (LMO) 4 as an important mediator of BLA-regulated behaviors. Mammalian genomes encode 4 LMO proteins, LMO1-4. LMO proteins interact via their LIM domains with transcription cofactors and regulatory DNA-binding proteins and regulate gene expression either by nucleating the formation of new transcriptional complexes or by disrupting existing complexes through competition with transcriptional coactivators (Heberlein et al., 2009; Matthews et al., 2013). Therefore, depending on the complement of transcriptional coregulators and transcription factors with which they interact, LMO proteins can either activate or repress gene expression. LMO proteins can also affect neuronal function independently of effects on transcription. For example, reducing LMO4 in the hypothalamus and the amygdala increases protein tyrosine phosphatase $1 \mathrm{~B}$ activity (PTP1B) via increased oxidation of this phosphatase. This regulation of PTP1B is important for hypothalamic leptin and amygdalar endocannabinoid signaling (Qin et al., 2012; Pandey et al., 2013).

Among the 4 mammalian Lmo genes, Lmo 4 is highly expressed in brain structures such as the BLA, orbitofrontal cortex (OFC), and NAc that are involved in regulating motivated behaviors (Heberlein et al., 2009; Lasek et al., 2010). Previously, we found that Lmo4 is expressed predominantly in pyramidal neurons of the BLA (Maiya et al., 2012). Mice with a genetrap (gt) insertion at the Lmo4 locus (Lmo4gt/+ mice) express 50\% less Lmo4 than their wild-type (WT) counterparts and display enhanced fear 
learning. BLA-specific knockdown of Lmo4 recapitulates this phenotype. These findings suggest that LMO4 functions in the BLA to negatively regulate fear learning.

Because the BLA is also involved in the processing of positive emotions, we investigated the role of LMO4 in cue-reward learning and the ability of reward-paired cues to influence goaldirected behavior. Our results reveal that global or BLA-specific reduction in LMO4 leads to a selective deficit in conditioned reinforcement, enhanced neuronal excitability, and reduced dopamine D2 receptor (D2R) expression and D2R-mediated signaling in the BLA.

\section{Materials and Methods}

Animals. The generation and characterization of mice with a gt insertion at the Lmo4 locus have been described previously (Heberlein et al., 2009; Lasek et al., 2010). We used 8- to 12-week-old, male, heterozygous Lmo4gt ( Lmo4gt/+) mice and their WT littermates on a C57B6/J background for behavioral and biochemical experiments, 5- to 8-week-old male and female $\mathrm{Lmo} 4 \mathrm{gt} / \mathrm{+}$ mice and their WT littermates for electrophysiological studies, and 8- to 12-week-old C57BL/6J mice for shRNA experiments. Mice were group housed until surgery, after which they were housed individually. For behavioral experiments and tissue collection for molecular and biochemical studies, mice were housed under a $12 \mathrm{~h}$ light/dark cycle with lights on at 7:00 AM and were euthanized for experiments between 9:00 AM and 2:00 PM. For electrophysiological studies, mice were housed under a $12 \mathrm{~h}$ light dark cycle with lights on at 12:00 AM. Mice were habituated to this cycle for a minimum of $14 \mathrm{~d}$. Mice were euthanized for electrophysiological experiments between 10:00 AM and 4:00 PM; recordings were performed between 12:00 PM and 1:00 AM.

Lentiviral shRNA constructs and stereotaxic surgery. The design and cloning of small hairpin RNAs against Lmo4 (designated as shLmo4) and control shRNA (designated as shCon) that does not target any gene in the mouse genome have been described previously (Lasek and Azouaou, 2010; Lasek et al., 2010; Maiya et al., 2012). Male C57BL/6J mice were infused bilaterally with $1 \mu \mathrm{l}$ of lentivirus $\left(10^{7}-10^{8} \mathrm{pg} / \mu \mathrm{l}\right)$ using a Hamilton syringe, as described previously (Lasek and Azouaou, 2010; Lasek et al., 2010; Maiya et al., 2012). The coordinates for BLA were $\mathrm{A} / \mathrm{P}=-1.6$, $\mathrm{M} / \mathrm{L}= \pm 3.1, \mathrm{D} / \mathrm{V}=-4.8$. The coordinates for the NAc were $\mathrm{A} / \mathrm{P}=$ $+1.43, \mathrm{M} / \mathrm{L}= \pm 0.9$, and $\mathrm{D} / \mathrm{V}=-4.55$. After injection, mice were allowed to recover for 2 weeks before behavioral testing. For investigating the role of the BLA in cue-reward learning, a total of 40 animals were injected (20 mice/shRNA). Ten animals were not included in the study due to off target or unilateral placements. For NAc knockdown experiments, a total of 28 animals were injected (14/group), of which six were excluded due to off-target or unilateral placements.

Quantitative PCR. WT and Lmo4gt/+ mice were killed and brains were rapidly frozen in isopentane and sectioned at $300 \mu \mathrm{m}$ thickness using a cryostat. Sections were frozen on dry ice and the BLA was punched from frozen sections using a 0.75 -mm-diameter stainless steel micropunch (Stoelting). RNA was extracted using the RNeasy kit from Qiagen according to the manufacturer's instructions. Complementary DNA (cDNA) was generated from $1 \mu \mathrm{g}$ of mRNA using the High Capacity cDNA Reverse Transcription Kit from Life Technologies. Gene expression was analyzed by quantitative RT-PCR using an Applied Biosystems Viia7 thermal cycler with TaqMan probes (Life Technologies) that detects Drd1 (Mm0260146_s1), Drd2 (Mm00438545_m1), and Drd3 (Mm00432887_m1). Expression levels were normalized to mouse Gapdh (Mm99999915_g1). Amplification reactions contained $5 \mu \mathrm{l}$ of cDNA template, $1 \times$ Universal PCR Master Mix, $100 \mathrm{~nm}$ each of forward and reverse primers, and 200 nм FAM- or VIC-labeled probe in a final volume of $10 \mu$ l. Relative expression levels were quantified by normalizing target amplicon Ct values to Gapdh.

Cue-reward learning. Cue-reward learning, conditioned reinforcement, and instrumental conditioning were tested as described previously (Mead and Stephens, 2003). Mice were food restricted to $85-90 \%$ of their body weight and were then trained to associate the presentation of discrete cues with a sucrose reinforcer in operant chambers (Med Associ- ates). Cues consisted of a $10 \mathrm{~s}$ presentation of lights with white noise and were delivered on a variable interval schedule with a mean interval of $120 \mathrm{~s}$. Reinforcer $(0.01 \mathrm{ml}$ of a $15 \%$ sucrose solution) was delivered $5 \mathrm{~s}$ after cue presentation. Head entry rates into the reward port during the presentation of the cue and during the intertrial interval (ITI) were recorded. Training consisted of 11 sessions (1session/d) lasting $2 \mathrm{~h}$ each. Mice were then tested for goal tracking ( $1 \mathrm{~h}$ session) by presenting them with cues previously paired with the reinforcer once every $2 \mathrm{~min}$. The reinforcer was not delivered during this session. Head entries into the reward port were monitored during the presentation of the cue and during the ITI. Immediately after the goal tracking session, mice were subjected to another conditioning session, as described above. Conditioned reinforcement was tested the day after goal tracking. Mice were placed in operant chambers and presented two nosepoke ports. Responses on the active port resulted in presentation of the cue previously paired with the reward. Responses on the inactive port had no consequence. The assignment of active and inactive ports was counterbalanced across genotypes and shRNAs. The number of active and inactive nosepokes was monitored in a $1 \mathrm{~h}$ session.

Instrumental conditioning. The day after testing for conditioned reinforcement, mice underwent instrumental conditioning. On day 1 of training, mice were placed in operant chambers with one active lever. Responses on the active lever resulted in the delivery of $0.01 \mathrm{ml}$ of a $15 \%$ sucrose reinforcer on an fixed ratio 1 (FR1) schedule, by which one active lever response results in one delivery of the reinforcer. The number of lever presses made in a $3 \mathrm{~h}$ session was recorded. On days $2-6$, a second, inactive lever was introduced into the chamber. The assignment of active and inactive levers was counterbalanced across genotypes and shRNAs. As before, responses on the active lever resulted in reinforcer delivery on an FR1 schedule, whereas responses on the inactive lever had no consequence. The percentage of active lever presses in a $2 \mathrm{~h}$ session was monitored every day from days 2-6.

Experimentally naive mice were trained to nosepoke on an FR1 schedule for a sucrose reinforcer. Mice were subjected to $1 \mathrm{~h}$ magazine training sessions in operant chambers (Med Associates) for $2 \mathrm{~d}$, during which sucrose reinforcer $(10 \mu \mathrm{l})$ was delivered on a random interval schedule with a mean interval of $120 \mathrm{~s}$. Mice were subsequently trained to nosepoke on an FR1 schedule to obtain a sucrose reinforcer. Each active nosepoke resulted in the $10 \mathrm{~s}$ presentation of a tone and light cue that coterminated with the delivery of sucrose. Inactive nosepokes had no programmed consequence. The assignment of active and inactive nosepokes was counterbalanced within and across genotypes. Mice were subjected to an overnight conditioning session on day 1 and $2 \mathrm{~h}$ conditioning sessions on days 2-8. Active and inactive nosepokes were recorded through all sessions.

Two-bottle choice sucrose consumption. Naive mice were individually housed for 1 week and given $24 \mathrm{~h}$ access to 2 bottles of water. Mice were then presented with one bottle containing sucrose solution and another containing water. The concentration of sucrose was escalated every $2-3 \mathrm{~d}$ in the following order: $2 \%, 6 \%$, and $15 \%$. The amount of sucrose and water consumed was measured every day and the positions of the bottles were alternated every day to control for side preferences. Drinking volumes were corrected for spillage by subtracting the amount of liquid lost from water and sucrose bottle placed on empty cages. The amount of sucrose consumed was normalized to body weight. Preference was expressed as the ratio of the amount of sucrose solution consumed to the total amount of fluid consumed.

Immunohistochemistry. To identify the extent of lentiviral infection, mice were anesthetized with Euthasol and perfused transcardially with $0.9 \%$ saline to remove blood and then with $4.0 \%$ paraformaldehyde (PFA) in PBS for $5 \mathrm{~min}$. Brains were removed, fixed in 4\% PFA overnight at $4^{\circ} \mathrm{C}$, and transferred to $30 \%$ sucrose solution at $4^{\circ} \mathrm{C}$, where they remained for $1-2 \mathrm{~d}$ until they were sectioned. Brains were mounted using Tissue-Tek OCT (Ted Pella) and $50 \mu \mathrm{m}$ free-floating sections were cut using a cryostat. The sections were then pretreated with $3 \% \mathrm{H}_{2} \mathrm{O}_{2}$ for 10 min, followed by $50 \%$ ethanol twice for $10 \mathrm{~min}$ each. Sections were blocked with 10\% normal donkey serum (NDS; Jackson Immunoresearch) for $30 \mathrm{~min}$ and incubated with mouse anti-GFP monoclonal antibody (3E10; Life Technologies) diluted 1:1500 in PBS with $0.1 \%$ 
Triton X-100 for $48 \mathrm{~h}$. Sections were washed for $5 \mathrm{~min} 3$ times with PBS and then incubated with $2 \%$ NDS for $10 \mathrm{~min}$. Biotin-conjugated donkey anti-mouse secondary antibody (diluted 1:250; Jackson Immunoresearch) was incubated with sections for $2-3 \mathrm{~h}$, followed by ExtrAvidin-Peroxidase $\quad(1: 2500$; SigmaAldrich) for 1-2 h. Diaminobenzidine was used for brown color detection of the GFP immunoreactivity. Sections were washed with PBS, mounted on gelatin-coated slides, and dried. Slides were counterstained with cresyl violet.

Electrophysiology. Mice were lightly anesthetized with isoflurane and their brains were rapidly removed and placed in ice-cold $\left(4^{\circ} \mathrm{C}\right)$ oxygenated high-sucrose cutting solution containing the following (in $\mathrm{mm}$ ): 210 sucrose, $26.2 \mathrm{NaHCO}_{3}, 1 \mathrm{NaH}_{2} \mathrm{PO}_{4}, 2.5 \mathrm{KCl}, 6 \mathrm{MgCl}_{2}$, $2.5 \mathrm{CaCl}_{2}$, and 11 dextrose, bubbled with $95 \%$ $\mathrm{O}_{2} / 5 \% \mathrm{CO}_{2}$. Coronal slices $(250 \mu \mathrm{m})$ containing the BLA were sectioned in ice-cold, highsucrose cutting solution using a Leica VT1000S vibrating microtome and then placed into artificial CSF (ACSF) containing the following (in mM): $124 \mathrm{NaCl}, 26 \mathrm{NaHCO}_{3}, 1 \mathrm{NaH}_{2} \mathrm{PO}_{4}, 4.4$ $\mathrm{KCl}, 1 \mathrm{MgCl}_{2}, 2 \mathrm{CaCl}_{2}, 10$ dextrose, and 0.075 Na-metabisulfite bubbled with $95 \% \mathrm{O}_{2} / 5 \%$ $\mathrm{CO}_{2}, \mathrm{pH}$ 7.4. Slices were maintained in ACSF at room temperature for at least $1 \mathrm{~h}$ before recording. Recordings were conducted at $30-$ $31^{\circ} \mathrm{C}$ in ACSF bubbled with $95 \% \mathrm{O}_{2} / 5 \% \mathrm{CO}_{2}$ and pumped into the recording chamber at

$\sim 2.0 \mathrm{ml} / \mathrm{min}$. Dopamine-containing ACSF $(10 \mu \mathrm{M})$ was made fresh daily by dissolving $9.5 \mathrm{mg}$ of dopamine in $250 \mathrm{ml}$ of ACSF. Recording electrodes (4-inch thin-wall glass, 1.5 outer diameter/1.12 inner diameter; World Precision Instruments) were made using a Brown-Flaming model $\mathrm{P}-88$ electrode puller (Sutter Instruments) to yield resistances between 3 and $6 \mathrm{M} \Omega$ and contained the following (in $\mathrm{mm}$ ): $120 \mathrm{KMeSO}_{4}$ (ACROS Organics) $10 \mathrm{NaCl}$, 0.5 EGTA, 10 HEPES, 4 Mg-ATP, 0.3 Na-GTP, and 14 phosphocreatine, $\mathrm{pH} 7.3$ with $\mathrm{KOH}$. Unless otherwise noted, chemicals were obtained from Sigma-Aldrich or Fisher Scientific.

Cells were visually identified based on their morphology using the MRK200 Modular Imaging system from Siskiyou mounted on a vibration isolation table. Recordings were acquired using a CV203BU headstage and Axopatch 200B amplifier (Molecular Devices), filtered at 1 $\mathrm{kHz}$, and digitized at $5 \mathrm{kHz}$ via a Digidata $1440 \mathrm{~A}$ interface board using Clampex 10.3 (Molecular Devices). Cells were included in analyses based on parameters measured immediately after obtaining whole-cell configuration (series resistance $<25 \mathrm{M} \Omega$ and a resting membrane potential less than $-65 \mathrm{mV}$ ) and firing patterns in response to depolarizing current injections that were consistent with features reported previously for BLA principal neurons (Kröner et al., 2005).

Data were analyzed using Clampfit 10.3 software (Molecular Devices). Input resistance was determined from the average of the voltage responses to small hyperpolarizing current pulses ( $-20 \mathrm{pA} ; 150 \mathrm{~ms}$ duration) delivered $150 \mathrm{~ms}$ before depolarizing current pulses. Excitability was measured by applying depolarizing intracellular current pulses (500 $\mathrm{ms}$ duration) of increasing amplitude (from 40 to $360 \mathrm{pA}$ in $40 \mathrm{pA}$ steps) once every $5 \mathrm{~s}$ to determine rheobase (minimum injected current that elicited an action potential) and the number of action potentials fired at each current amplitude. The action potential threshold was defined as the membrane potential at the initial point of rapid voltage deflection and action potential amplitude was measured from this voltage. Action potential half-width was the duration of the action potential at halfamplitude. To evaluate the effect of dopamine on excitability, we delivered the previously described series of depolarizing current injections once every $4 \mathrm{~min}$ for at least $12 \mathrm{~min}$ to establish a stable baseline. Dopa-
B
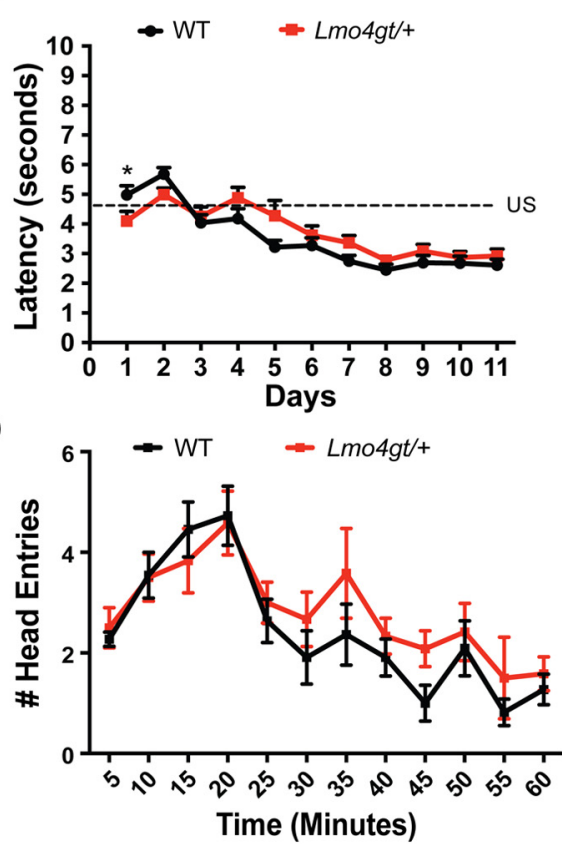

Figure 1. Lmo4gt/+ and WT mice show similar cue-reward learning. $\boldsymbol{A}$, WT and $L m o 4 g t /+$ mice increased head entry rates by Bonferroni test; $n=15$ WT, $n=18 \mathrm{Lmo4gt} /+$ mice). $\boldsymbol{B}$, Latency for head entries into the reward port after cue onset decreased ine in both groups. ${ }^{*} p=0.048$, Bonferroni test. $\boldsymbol{C}$, During goal tracking, both genotypes increased head entries during mine was then washed on for $\sim 4$ min and recording continued for at least 25 min thereafter.

Western blotting. Lmo4gt/+ mice and their WT littermates were administered $1 \mathrm{mg} / \mathrm{kg}$ quinpirole hydrochloride (Sigma-Aldrich) or saline intraperitoneally. Thirty minutes later, mice were killed by cervical decapitation, their brains were rapidly removed, and the BLA was dissected using a $1 \mathrm{~mm}$ biopsy punch. Tissue was flash frozen in liquid nitrogen and stored at $-80^{\circ} \mathrm{C}$ until further processing. Tissue was homogenized in $1 \%$ SDS containing $2 \mu \mathrm{M}$ okadaic acid using a glass pestle. The homogenate was boiled for $10 \mathrm{~min}$ and centrifuged at $10,621 \times g$ for $5 \mathrm{~min}$. Supernatant was collected and protein concentrations were measured using the bicinchonnic acid assay method (Life Technologies). Protein (40 $\mu \mathrm{g}$ ) was resolved on a 10\% SDS-polyacrylamide gel and transferred onto a nitrocellulose membrane. After transfer, the membrane was blocked with 5\% BSA in Tris-buffered saline containing $0.1 \%$ Tween (TBST) for $1 \mathrm{~h}$, followed by overnight incubation with 1:1000 dilution of anti P-Thr ${ }^{308}$ AKT antibody (Cell Signaling Technology) in 5\% BSA in TBST. Immune complexes were detected by appropriate peroxidaseconjugated secondary antibodies (Jackson Immunoresearch), followed by chemiluminiscent detection (Supersignal-West Pico; Life Technologies). Membranes were stripped and probed using an antibody against AKT (1:1000 in 5\% milk in TBST; Cell Signaling Technology). Densitometric analyses was performed using ImageJ (Schneider et al., 2012). Phosphoprotein levels were normalized to total protein levels.

Statistical analyses. Electrophysiological data were analyzed using IBM SPSS Statistics 21. Other data were analyzed using GraphPad Prism 6.0. Statistical significance was defined as $p<0.05$ for group comparisons using an unpaired, two-tailed $t$ test or two-way ANOVA with a Bonferroni post hoc test, as appropriate. Summary data are presented as mean values \pm SEM.

\section{Results}

To determine whether LMO4 is important for cue-reward learning, we first investigated the ability of WT and $\mathrm{Lmo} 4 \mathrm{gt} /+$ mice to associate cues with the delivery of $15 \%$ sucrose as an appetitive reinforcer (Fig. 1A). Both groups increased the rate of head en- 
A

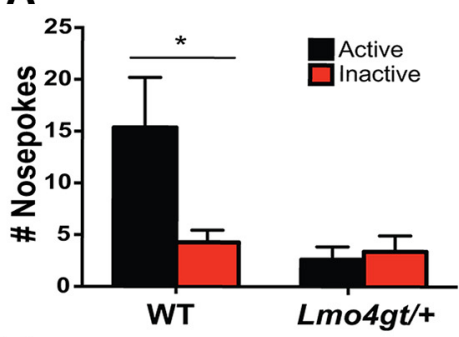

D

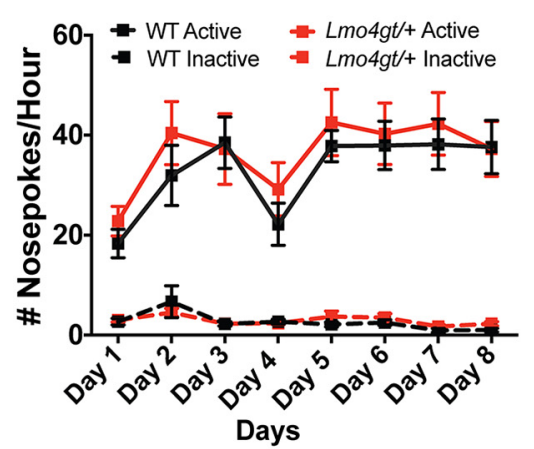

B

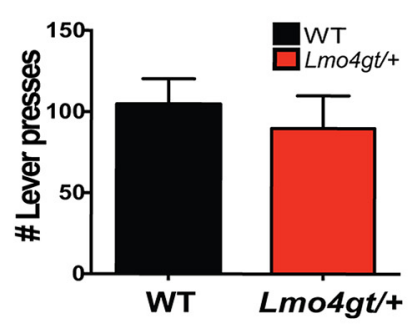

E

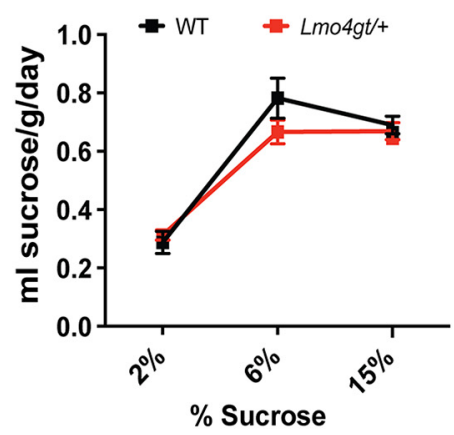

C
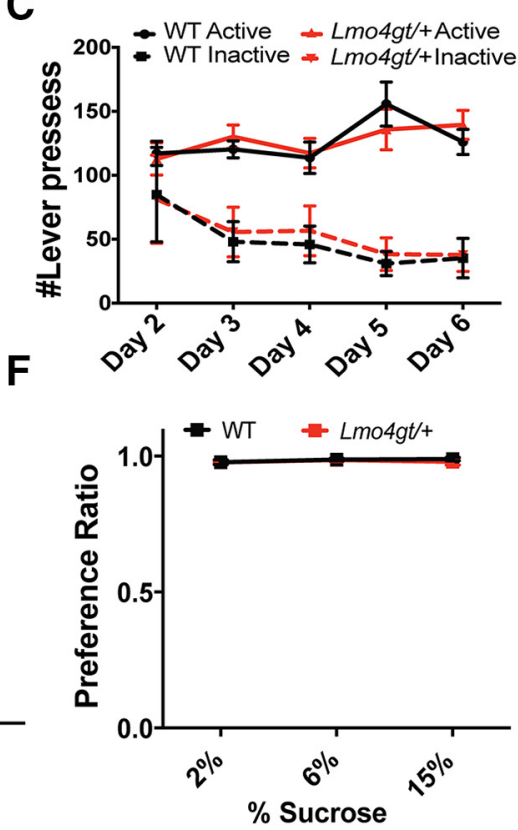

Figure 2. $\quad \boldsymbol{A}, \mathrm{Lmo} \mathrm{gt} / \mathrm{+}$ mice show a selective deficit in conditioned reinforcement. WT mice made significantly more active than inactive nosepokes, whereas $\mathrm{Lmo}$ mgt/ + mice did not discriminate between active and inactive ports. ( ${ }^{*} p=0.01$, Bonferroni test; $n=14 \mathrm{WT}$ and $n=13 \mathrm{Lmo} \mathrm{gt} /+$ mice). $\boldsymbol{B}$, The number of reinforcers obtained on day 1 of instrumental conditioning was similar in both genotypes. C, With training, both WT and $L m 04 \mathrm{gt} /+$ mice increased the number of active and decreased the amount of inactive lever presses. ( $n=7 /$ genotype). $\boldsymbol{D}$, Both WT and $\mathrm{Lmo4gt/+} \mathrm{mice} \mathrm{were} \mathrm{equally} \mathrm{proficient} \mathrm{in} \mathrm{performing} \mathrm{a} \mathrm{nosepoke} \mathrm{response} \mathrm{on} \mathrm{an} \mathrm{FR1} \mathrm{schedule} \mathrm{to} \mathrm{obtain} \mathrm{a} \mathrm{sucrose} \mathrm{reinforcer}(n=8 \mathrm{WT}$ and $n=13 \mathrm{Lmo4gt} /+)$. $\boldsymbol{E}$, Significant differences were not observed in the amount of sucrose consumed or in the preference ratio $(\boldsymbol{F})$ between WT and $L \mathrm{mo} \mathrm{gt} / \mathrm{f}$ mice $(n=7, \mathrm{Lmo} \mathrm{gt} / \mathrm{L} ; n=8 \mathrm{WT})$.

tries into the reward port during cue presentation $\left(F_{\text {Day }(10,310)}=\right.$ 17.67, $p<0.0001)$. Although the increase in head entries was greater in WT mice early in training $\left(F_{\text {Genotype }} \times\right.$ Day(10,310) $=2.03$, $p=0.0301)$, WT and Lmo4gt/+ mice differed significantly only on conditioning day 4. Importantly, head entry rates during cue presentation were identical for both genotypes from day 5 through the end of the training period. Conversely, during the ITI (Fig. 1A), mice of both genotypes decreased head entries into the reward port with training $\left(F_{\operatorname{Day}(10,310)}=63.98, p<0.0001\right)$. Although this decrease was slightly greater in WT mice on days 3 and 4 of training $\left(F_{\text {Genotype }} \times \operatorname{Day}(10,310)=1.992, p=0.03\right)$, the number of head entries did not differ between genotypes after day 4.

We also investigated the latency to make head entries into the reward port after cue onset (Fig. 1B). With training, both $\mathrm{WT}$ and $\mathrm{Lmo} 4 \mathrm{gt} / \mathrm{H}$ mice reduced their latencies $\left(F_{\mathrm{Day}(10,310)}=\right.$ $41.18, p<0.0001)$. Although there was a slight delay in latency reduction in $\mathrm{Lmo} 4 \mathrm{gt} /+$ mice $\left(F_{\text {Genotype }} \times \operatorname{Time}(10,310)=4.064\right.$, $p<0.0001)$, differences between the genotypes were small and apparent only on days 2 and 5; latencies were identical thereafter. Finally, we examined the ability of reward-paired cues to elicit approach to the reward port ("goal tracking"; Fig. 1C). Both WT and Lmo4gt/+ mice showed more head entries into the reward port during cue presentation than during the ITI $\left(F_{\text {Cue }(1,64)}=356.46, p<0.0001 ; F_{\text {Genotype }(1,64)}=1.93, p=\right.$ $\left.0.17 ; F_{\text {Genotype } \times \text { Cue }(1,64)}=2.75, p=0.1\right)$. We also compared within-session extinction of goal tracking responses in WT and $\mathrm{Lmo} 4 \mathrm{gt} / \mathrm{+}$ mice (Fig. $1 D$ ). Head entries into the reward port during CS presentation decreased similarly in both genotypes over time $\left(F_{\text {Time }(11,231)}=10.23, p<0.0001 ; F_{\text {Genotype }(1,21)}=1.247, p=0.28\right.$; $\left.F_{\text {Genotype } \times \text { Time }(11,231)}=0.59, p=0.84\right)$. These results indicate that both acquisition and extinction of cue-reward learning are intact in Lmo4gt/+ mice.
We next investigated the ability of reward-paired stimuli to act as conditioned reinforcers and support the acquisition of novel instrumental tasks. Mice were placed in operant chambers with two nosepoke ports. Nosepokes into the active port resulted in the presentation of the cue that was previously paired with the reward, whereas nosepokes into the inactive port had no consequence. WT, but not $L m o 4 g t /+$ mice, made significantly more active than inactive nosepokes $\left(F_{\text {Genotype }} \times \operatorname{Nosepoke(1,50)}=4.61\right.$, $p=0.03$; Fig. $2 A$ ). This result was not due to impaired locomotion because we found previously that $\mathrm{Lmo} 4 \mathrm{gt} /+$ mice are not impaired in exploration of a novel open field (Lasek et al., 2010). This behavioral deficit also cannot be explained by reduced motivation to consume sucrose because, in the home cage, WT and Lmo4gt/ + mice consumed similar amounts of sucrose (Figs. $2 E, F)$. Such a deficit could arise from an inability to learn the association between the stimulus and the reward, an inability to assign motivational properties to reward-paired cues, or impairments in instrumental conditioning because conditioned reinforcement requires the learning of a novel instrumental task. Our results shown in Figure 1, $A-C$, clearly indicate that $L m o 4 g t /+$ mice do not have deficits in learning of cue-reward associations. To distinguish between the other two possibilities, we investigated instrumental conditioning. On the first day of conditioning, WT and Lmo4gt/+ mice showed a similar ability to lever press for sucrose on an FR1 schedule (Fig. 2B). On subsequent days (day 2-6), a second, inactive lever that did not result in reinforcer delivery was introduced and the mice had to learn to discriminate between active and inactive levers (Fig. 2C). With training, both genotypes learned to press the active lever equally well $\left(F_{\text {Day }(4,48)}=3.67, p=0.01 ; F_{\text {Genotype }(1,12)}=0.001, p=0.96\right.$; $\left.F_{\text {Genotype } \times \operatorname{Day}(4,48)}=0.96, p=0.44\right)$ and to decrease their responses on the inactive lever $\left(F_{\text {Day }(4,48)}=5.05, p=0.002\right.$; $\left.F_{\text {Genotype }(1,12)}=0.04, p=0.85, F_{\text {Genotype } \times \text { Day }(4,48)}=0.1, p=0.98\right)$. 

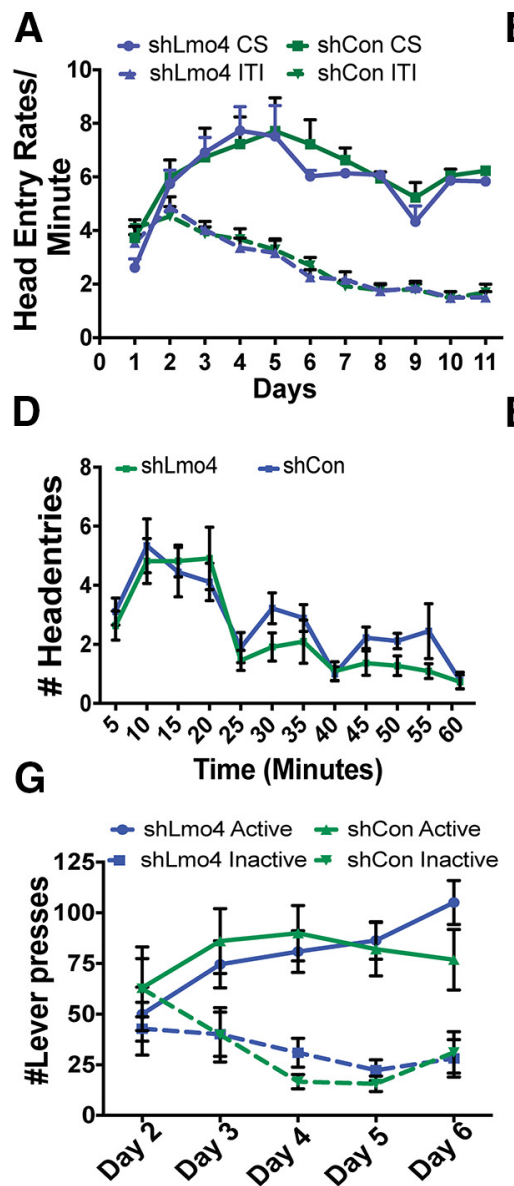

B
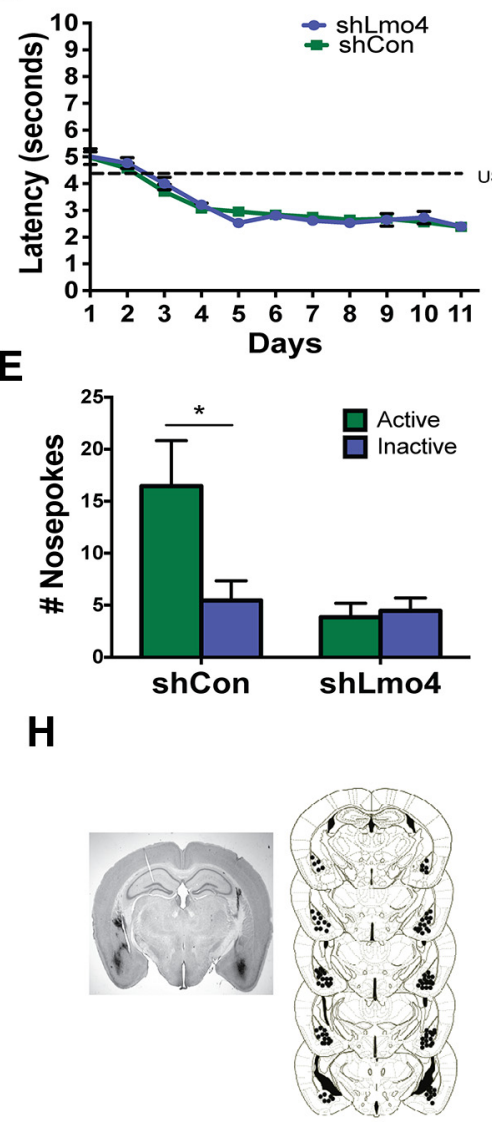

C

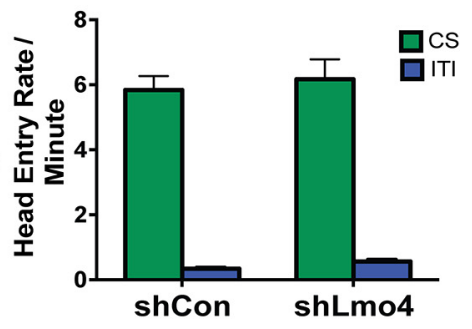

$\mathbf{F}$

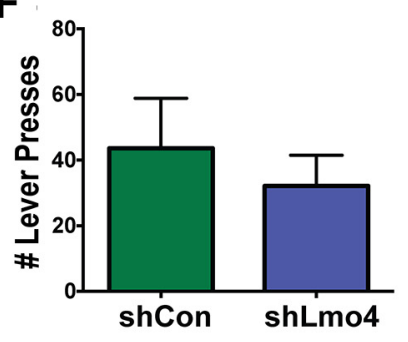

Figure 3. Knockdown of $L m 04$ in the BLA does not affect cue-reward associations. $A$, During conditioning, mice injected with shCon ( $n=13)$ or shLmo4 ( $n=15)$ made more head entries during presentation of the cue than during the ITI. $\boldsymbol{B}$, No differences were observed in latencies to enter the reward port after cue onset between shCon- and shLmo4-injected mice across training sessions. C, During goal tracking sessions, both groups made more head entries during the presentation of the cue than during the ITI. $\boldsymbol{D}$, Differences were not observed between the groups in extinction of goal tracking. $\boldsymbol{E}$, During the conditioned reinforcement session, shCon-injected mice made significantly more active than inactive nosepokes, whereas shLmo4-injected mice failed to discriminate between active and inactive nosepokes ( ${ }^{*} p=0.002$, Bonferroni test, $n=13$ ). $\boldsymbol{F}$, No significant difference was observed in the number of reinforcers obtained between the groups on day 1 of the instrumental conditioning session. $\boldsymbol{G}$, Both shCr- and shLmo4-injected mice increased the number of active lever presses and decreased the number of inactive lever presses with training. $\boldsymbol{H}$, Left, Coronal section showing GFP immunoreactivity indicating viral infection in the BLA. Right, Serial reconstruction of microinjection sites.

We also compared nosepoke responding for sucrose on an FR1 schedule in WT and Lmo4gt/+ mice (Fig. 2D). Both genotypes increased active nosepoke responding with training $\left(F_{\text {Day }(7,152)}=\right.$ 3.077, $p=0.005 ; \quad F_{\text {Genotype(1,152) }}=1.534, p=0.2174$; $\left.F_{\text {Genotype } \times \operatorname{Day}(7,152)}=0.1596, p=0.99\right)$. Inactive nosepoke responding remained low in both genotypes and decreased with training $\left(F_{\text {Day }(7,133)}=5.011, p<0.0001 ; F_{\text {Genotype }(1,19)}=0.2735, p=\right.$ $\left.0.61 ; F_{\text {Genotype }} \times \operatorname{Day}(7,133)=1.032, p=0.42\right)$. These results indicate that $L m o 4 g t /+$ mice are not impaired in acquisition of a discriminative instrumental conditioning task. Together, our results indicate that the deficit in conditioned reinforcement in Lmo4gt/+ mice is due to impaired ability to assign motivational value to reward-paired stimuli rather than general impairments in instrumental learning, sucrose preference, extinction learning, or motor performance.

This selective deficit in conditioned reinforcement that we observed in $\mathrm{Lmo} 4 \mathrm{gt} /+$ mice is reminiscent of rats with BLA lesions (Baxter and Murray, 2002). Therefore, we investigated whether knockdown of Lmo4 in the BLA would be sufficient to reproduce this phenotype. We used an shRNA that we found reduces $L m o 4$ mRNA in the BLA by $44 \%$ and also reduces LMO 4 protein (Maiya et al., 2012). An shCon not targeting any gene in the genome was used as a control (Maiya et al., 2012). Knockdown of Lmo4 in the BLA did not impair the acquisition of cue- reward learning $\left(\mathrm{CS}: F_{\operatorname{Day}(10,260)}=10.95, p<0.0001 ; F_{\text {shRNA }(1,26)}=\right.$ $0.4158, p=0.5247 ; F_{\text {shRNA }} \times \operatorname{Day}(10,260)=0.5130, p=0.88$; Fig. $3 A$ ) or the rate of head entry into the reward port during the ITI across training sessions $\left(F_{\operatorname{Day}(10,260)}=40.93, p<0.0001\right.$; $F_{\text {shRNA }(1,26)}=0.06882, p=0.8 ; F_{\text {shRNA }} \times \operatorname{Day}(10,260)=0.5827, p=$ $0.82)$. There were also no differences between the groups in latency to enter the reward port $\left(F_{\operatorname{Day}(10,260)}=50.77, p<0.0001\right.$; $F_{\text {shRNA }(1,26)}=0.08, p=0.8 ; F_{\text {shRNA } \times \operatorname{Day}(10,260)}=0.6166, p=0.8$; Fig. $3 B$ ), head entry rates into the reward receptacle during the presentation of the cue alone in a goal tracking session $\left(F_{\mathrm{Cue}(1,56)}=\right.$ $255.11, p<0.0001 F_{\text {shRNA }(1,56)}=1.324, p=0.25 ; F_{\text {shRNA }} \times \operatorname{Cue}(1,56)=$ $0.28, p=0.6$; Fig. $3 C)$, or in the rate of extinction of goal tracking responses $\left(F_{\text {Time }(11,198)}=12.97, p<0.0001 ; F_{\text {shRNA }(1,18)}=3.468, p=\right.$ $0.08 ; F_{\text {shRNA } \times \text { Time }(11,198)}=0.6662, p=0.77 ;$ Fig. $\left.3 D\right)$. However, conditioned reinforcement was impaired in mice that received the shRNA against $\operatorname{Lmo} 4\left(F_{\text {Nosepoke } \times \operatorname{shRNA}(1,48)}=5.2, p=0.03\right.$; Fig. $\left.3 E\right)$. Significant differences were not observed between the two shRNAs in the number of active lever presses made on day 1 of conditioning (Fig. $3 F$ ). Analyses of active lever presses on days 2-6 indicate a significant genotype $\times$ $\operatorname{shRNA}$ interaction $\left(F_{\text {shRNA }} \times\right.$ Day $\left.(4,112)=2.949, p=0.0232\right)$. This interaction is likely driven by small differences in the number of active lever presses made by shLmo4-injected mice on days 2 and 6 compared with shCon mice. However, these differences were not significant by post hoc 


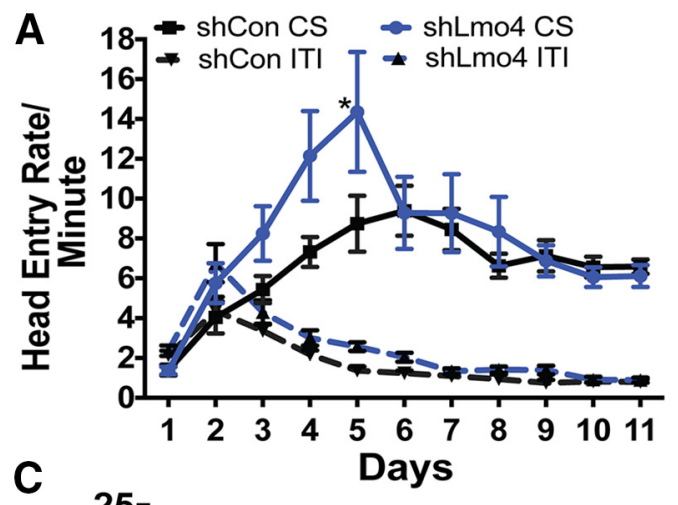

C

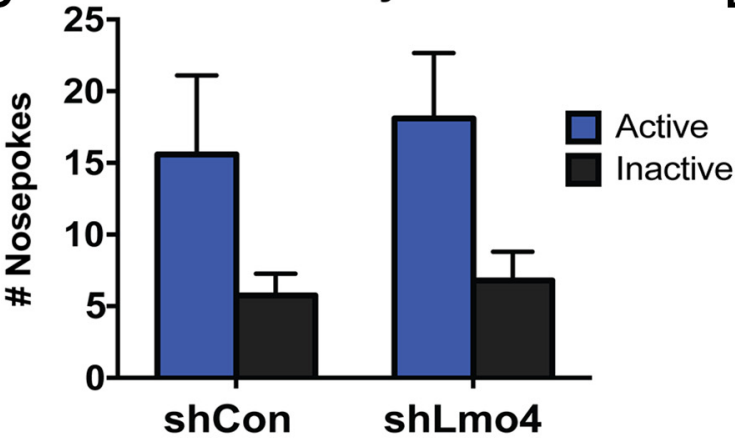

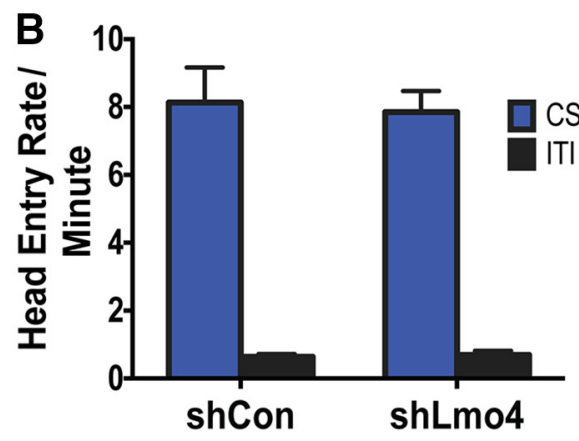

D
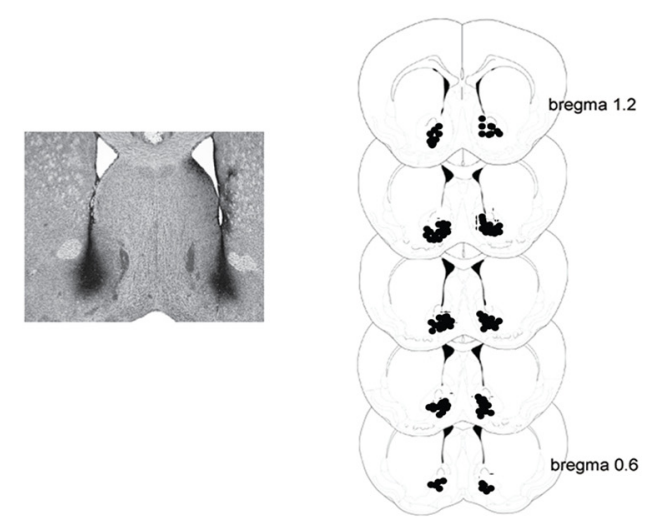

Figure 4. Knockdown of $L$ mo4 in the NAc does not affect conditioned reinforcement. $A$, Mice injected with shCon $(n=12)$ or sh $L$ mo $(n=10)$ made more head entries into the reward port during the CS than during the ITI; shLm04-injected mice made more head entries than shCon-injected mice only on day 5 ( ${ }^{*} p=0.0146$, Bonferroni test). $\boldsymbol{B}$, During goal tracking sessions, shCon- and shLmo4-injected mice made more head entries during the presentation of the cue than during the ITI. C, During conditioned reinforcement, both groups made more active than inactive nosepokes. D, Left, GFP staining indicating viral infection in the BLA. Right, Serial reconstruction of microinjection sites.

tests (Fig. $3 G$ ). The number of inactive lever presses decreased with training in both groups $\left(F_{\text {Day }(4,112)}=4.41 ; p=0.0024 ; F_{\text {shRNA }(1,28)}=\right.$ $0.0001 ; p=0.98 ; F_{\text {shRNA }} \times$ Day(4,112) $\left.=0.98 ; p=0.4226\right)$. Importantly, these analyses did not detect a deficit in the acquisition of instrumental conditioning in shLmo4-injected mice. These results indicate that knockdown of LMO4 in the BLA is sufficient to selectively impair cuereward learning and replicate the phenotype we observed in Lmo4gt/+ mice.

Projections from the BLA to the NAc are implicated in cuereward association and reward-seeking behavior (Di Ciano and Everitt, 2004; Ambroggi et al., 2008; Stuber et al., 2011). There is also electrophysiological evidence that information about the motivational value of reward-paired cues is encoded in both the BLA and the NAc (Di Ciano and Everitt, 2004; Ambroggi et al., 2008; Stuber et al., 2011). Importantly, medium spiny neurons in the NAc, which are targets of efferent projections from the BLA, also express Lmo4 (Lasek et al., 2010). Therefore, we investigated the consequences of knockdown of Lmo4 in the NAc. Our previous study showed that shLmo4 reduced both Lmo4 mRNA (by $50 \%$ ) and protein in lentivirus-infected medium spiny neurons in the NAc (Lasek et al., 2010). We found that shLmo4 and shCon-injected mice both learned to associate cue presentation with reinforcer delivery (Fig. 4A), although shLmo4-injected mice appeared to learn the task faster than their shCon-injected counterparts $\left(F_{\text {shRNA }} \times \operatorname{Day}(10,200)=2.334, p=0.0127\right)$. However, head entry rates between the groups only differed significantly on day 5 and rates were identical thereafter. In the goal-tracking session, both shCon- and shLmo4-injected mice made significantly more head entries during the presentation of the cue than during the intertrial interval $\left(F_{\text {Cue }(1,40)}=157, p<0.0001\right.$; $F_{\text {shRNA }(1,40)}=0.04, p=0.04 ; F_{\text {shRNA }} \times \operatorname{Cue}(1,40)=0.08, p=0.77$;
Table 1. Electrophysiological properties of BLA projection neurons from WT and Lmo4gt/+ mice

\begin{tabular}{lcc}
\hline & WT & Lmo4gt/+ \\
\hline$n$, cells (mice) & $13(6)$ & $17(8)$ \\
Resting membrane potential & $-68.0 \pm 0.6$ & $-68.7 \pm 0.5$ \\
Input resistance, $\mathrm{M} \Omega$ & $134.3 \pm 5.0$ & $186.3 \pm 11.8^{a}$ \\
Rheobase current, $\mathrm{pA}$ & $172 \pm 11$ & $120 \pm 10^{a}$ \\
Action potential threshold, $\mathrm{mV}$ & $-41.1 \pm 0.8$ & $-41.5 \pm 0.7$ \\
Action potential amplitude, $\mathrm{mV}$ & $75.3 \pm 2.3$ & $71.9 \pm 2.1$ \\
Action potential half-width, ms & $1.35 \pm 0.04$ & $1.42 \pm 0.07$ \\
AHP amplitude, $\mathrm{mV}$ & $8.3 \pm 0.8$ & $7.2 \pm 0.7$ \\
\hline
\end{tabular}

Significant difference versus WT ( $p<0.01$ ) using two-tailed, unpaired $t$ test.

Fig. 4B). Both shCon- and shLmo4-injected mice also displayed conditioned reinforcement $\left(F_{\text {Nosepokes }(1,40)}=7.432, p=0.009\right.$; $F_{\text {shRNA }(1,40)}=0.2117, p=0.65 ; F_{\text {Nosepokes } \times \operatorname{shRNA}(1,40)}=0.04, p=$ 0.85 ; Fig. $4 C$ ). Together, these results indicate that downregulation of Lmo 4 in the NAc may accelerate acquisition of cue-reward associations without affecting conditioned reinforcement.

Because knockdown of LMO4 in the BLA impaired cue-reward learning, we investigated whether electrophysiological properties of BLA neurons in Lmo4gt/+ mice are altered by performing whole-cell patch-clamp recordings in current-clamp mode. The resting membrane potential and the threshold potential for firing action potentials in response to depolarizing current injection were similar in BLA neurons from WT and Lmo4gt/+ mice, as were other action potential characteristics, such as amplitude, half-width, and the afterhyperpolarization (AHP) amplitude (Table 1). However, BLA neurons from Lmo4gt/+ mice exhibited several features of increased excitability, such as greater input resistance and lower rheobase current (the amplitude of 
A

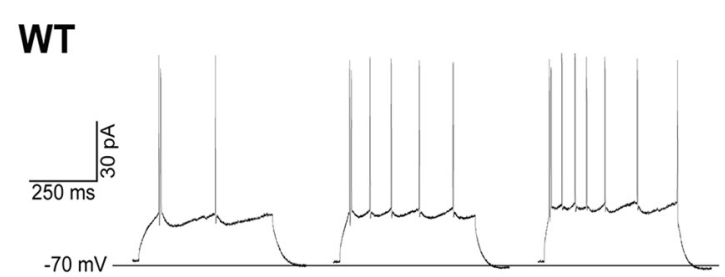

\section{Lmo4gt/+}

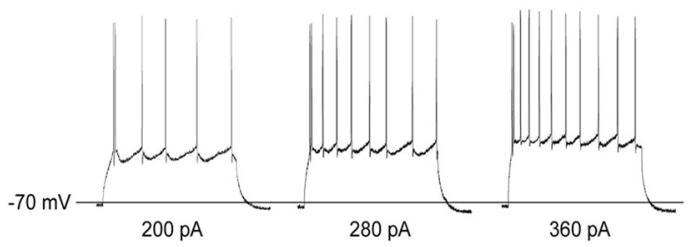

B

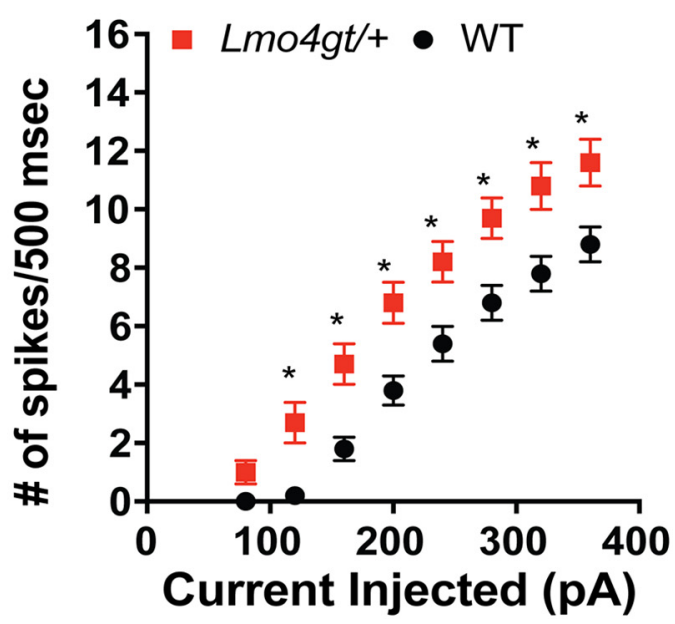

Figure 5. BLA pyramidal neurons from Lmo4gt/+ mice show increased excitability. $A$, Representative traces for neurons from WT (top) and $L m 04 g t /+$ (bottom) mice showing action potentials evoked by 200,280 , and 360 pA current steps. $\boldsymbol{B}$, Neurons from $\mathrm{Lmo} 4 \mathrm{gt} /+$ mice $(n=17$ ) showed greater action potential firing in response to increasing amplitudes of 500 ms depolarizing current injections relative to WT $(n=13)\left({ }^{*} p<0.05\right.$, Bonferroni test).

depolarizing current injection necessary to evoke action potential firing; Table 1). Moreover, the escalation in action potential firing in response to increasing depolarizing steps $\left(F_{\text {Amplitude }(9,252)}=\right.$ 255.7, $p<0.0001)$ was not the same for both genotypes $\left(F_{\text {Amplitude }} \times\right.$ Genotype $\left.(9,252)=6.087, p<0.0001\right)$ and, overall, Lmo4gt/ + BLA neurons displayed greater spike firing $\left(F_{\text {Genotype }(1,28)}=\right.$ $10.61, p=0.003$; Fig. $5 A, B)$. Together, these findings suggest that Lmo4gt/+ BLA neurons are more responsive than WT BLA neurons to excitatory inputs.

The ability of cues to act as conditioned reinforcers and support responding under second-order schedules of reinforcement is dependent upon dopamine signaling in the BLA. Bilateral infusions of D1, D2, or D3R antagonists into the BLA impair second-order conditioning (Di Ciano and Everitt, 2004; Di Ciano and Everitt, 2005; Di Ciano, 2008) and block cue-induced reinstatement to cocaine seeking (Berglind et al., 2006). Therefore, we compared Drd1, Drd2, and Drd3 expression in the BLA of WT and Lmo4gt/+ mice by quantitative PCR (qPCR). We observed a striking reduction in Drd $2 \mathrm{mRNA}$, but no change in Drd1 mRNA in the BLA of $\mathrm{Lmo} 4 \mathrm{gt} /+$ mice (Fig. 6A). We were unable to detect Drd3 mRNA using commercial qPCR assays in the BLA of either WT or $\mathrm{Lmo} 4 \mathrm{gt} /+$ mice.

To determine whether reductions in Drd2 mRNA levels lead to functional deficits, we compared D2R-mediated signaling in the BLA of WT and Lmo4gt/+ mice. Stimulation of the D2-like receptors rapidly increases phosphorylation of AKT at $\mathrm{Thr}^{308}$ of $\mathrm{D} 2 \mathrm{R}$ in primary cultures and in vivo in the NAc (Brami-Cherrier et al., 2002; Mannoury la Cour et al., 2011). In contrast, prolonged elevation of dopaminergic tone in the NAc, reduces Thr ${ }^{308}$ AKT phosphorylation (Beaulieu et al., 2005; Beaulieu et al., 2007; Beaulieu et al., 2011). The effect of D2R activation on AKT phosphorylation in the BLA is not known. We examined P-Thr ${ }^{308}$ levels in the BLA of WT and Lmo4gt/+ mice $30 \mathrm{~min}$ after a systemic administration of the selective D2/3R agonist quinpirole (Fig. 6B,C; Brami-Cherrier et al., 2002; Mannoury la Cour et al., 2011). P-Thr ${ }^{308}$ AKT levels were similar in BLA tissue from saline-treated WT and $L m o 4 g t /+$ mice (P-Thr ${ }^{308} /$ Total $\mathrm{AKT}$ ratio values for $\mathrm{WT}=0.46 \pm 0.05, \mathrm{Lmo} 4 \mathrm{gt} /+=0.513 \pm$ $0.07, p=0.5626$, Student's $t$ test, $n=8-10$ /genotype). However, quinpirole significantly enhanced P-Thr ${ }^{308}$ levels in WT, but not in Lmo4gt/+ mice (Figs. $6 \mathrm{~B}, \mathrm{C}$ ), indicating a deficit in $\mathrm{D} 2 / 3 \mathrm{R}$ signaling in $\mathrm{Lmo} 4 \mathrm{gt} /+$ mice.

Dopamine activates BLA neurons through a mechanism that requires both D1Rs and D2Rs (Kröner et al., 2005). Because both D2R expression and D2/3R-induced activation of Akt were reduced in the BLA of Lmo4gt/+ mice, we predicted that dopamine-induced activation of $\mathrm{Lmo} 4 \mathrm{gt} / \mathrm{H}$ - BLA neurons would also be reduced. Brief ( $\sim 4 \mathrm{~min})$ bath application of dopamine $(10 \mu \mathrm{M})$ significantly increased the firing frequency of BLA pyramidal neurons in response to depolarizing current injection in both genotypes, although the effect was much greater in WT neurons than in Lmo4gt/ + neurons $\left(F_{\text {Dopamine(10,110) }}=7.2, p<\right.$

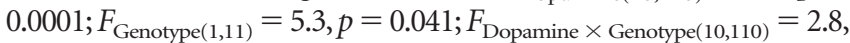
$p=0.0039$; Fig. $6 D-F)$. Therefore, the ability of BLA pyramidal neurons to respond dynamically to dopamine is compromised in $\mathrm{Lmo} 4 \mathrm{gt} /+$ mice.

\section{Discussion}

Our results reveal a novel role for the transcriptional regulator Lmo4 in attributing motivational significance to reward-paired cues. Lmo4gt/ + mice are as adept as their WT counterparts in learning the association between cue presentations and reinforcer delivery. However, they are deficient in subsequently using these reward-paired cues as conditioned reinforcers to learn a novel instrumental task. Lmo4gt/+ mice are not impaired in instrumental conditioning, so their deficit in conditioned reinforcement is due to their inability to assign motivational significance to reward-paired cues. Knockdown of Lmo4 in the BLA recapitulated this selective deficit in conditioned reinforcement, indicating that this phenotype is not due to a developmental abnormality in Lmo4gt/+ mice. This phenotype is likely related to a change in BLA pyramidal cell function because electrophysiological studies indicated enhanced excitability, but impaired dopamine-induced excitation of BLA neurons in $\mathrm{Lmo} 4 \mathrm{gt} /+$ mice. This impaired response to dopamine is likely due to the striking reduction in Drd2 expression and D2-mediated signaling in the BLA.

In the context of cue-reward learning, the BLA facilitates the association of reward-paired cues with the motivational properties of the reward. This information is then transmitted from the 

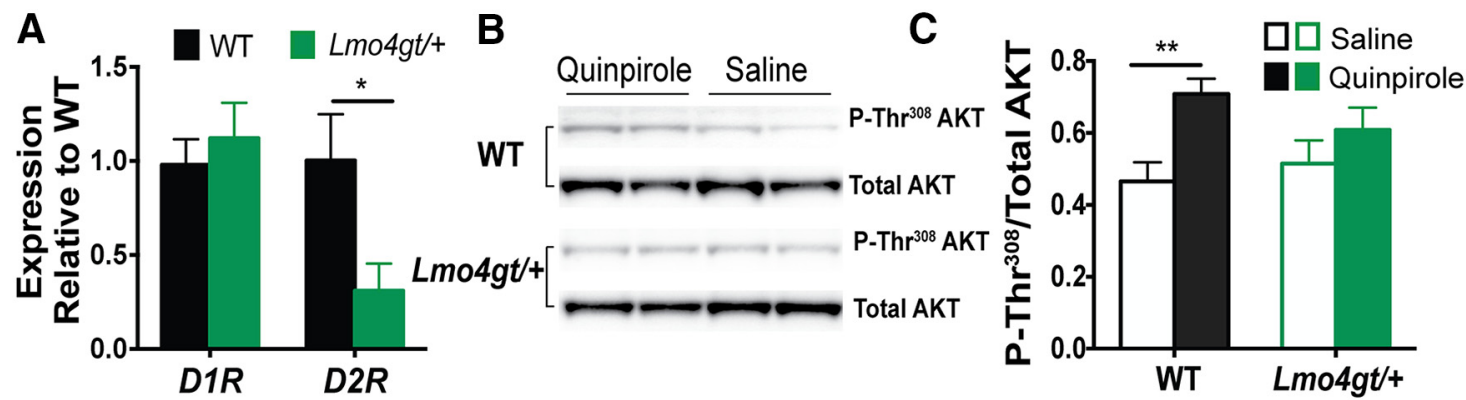

D

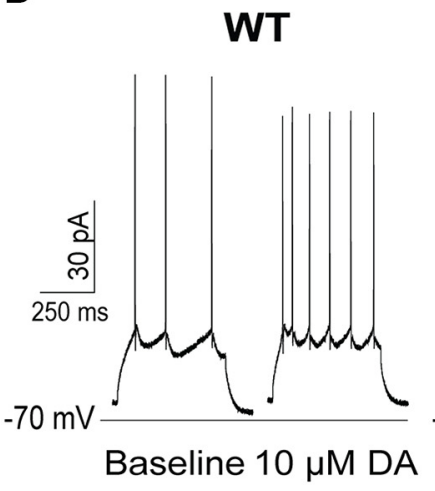

E

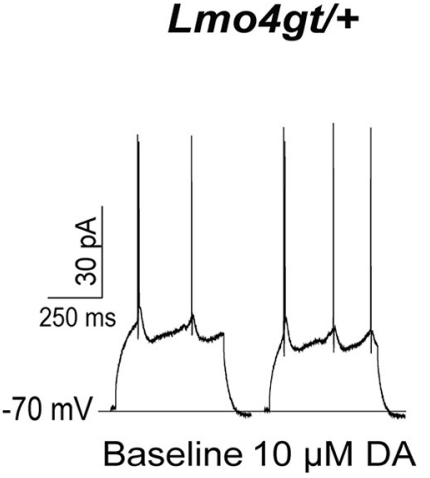

$\mathbf{F}$

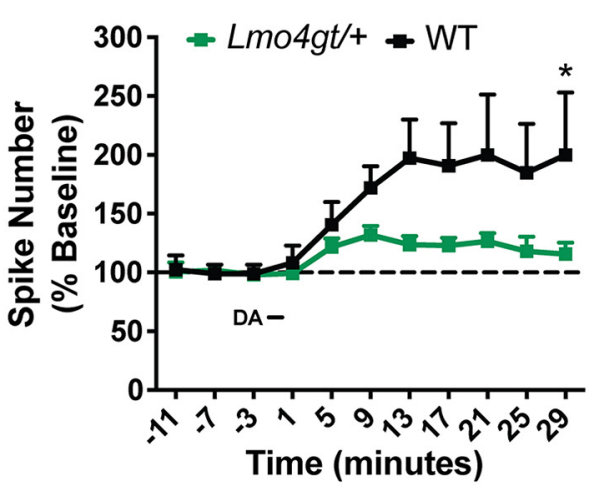

Figure 6. D2R abundance and signaling are reduced in the BLA of $L m 04 g t /+$ mice. $A, B L A$ of WT $(n=6)$ and $L m o 4 g t /+(n=8)$ mice showed similar levels of Drd1 mRNA, but there was a striking reduction in Drd2 mRNA the BLA of Lmo4gt/+ mice compared with WT mice ( ${ }^{*} p=0.04$, two-tailed $t$ test). B, C, Systemic administration of 1 mg/kg quinpirole increased P-Thr ${ }^{308}$ AKT immunoreactivity in the BLA of WT, but not $L$ mo4gt/ + mice $\left({ }^{* *} p=0.0045\right.$, two-tailed $t$ test; $n=10-11$ WT and $n=8-9 \mathrm{Lmo} g \mathrm{gt} /+$ mice $) . \boldsymbol{D}-\boldsymbol{F}, \mathrm{BLA}$ pyramidal neurons from Lmo4gt/ + mice are less responsive to dopamine. Representative traces for WT $(\boldsymbol{D})$ and $\mathbf{L m o 4 g t /}+(\boldsymbol{E})$ neurons show action potentials evoked by $500 \mathrm{~ms}$ depolarizing current injection before and after bath application of dopamine. $\boldsymbol{F}$, Time course for the effect of dopamine (DA) on spike firing. Data shown are mean \pm SEM values derived from the current amplitude that elicited the maximal change in spike number relative to the baseline average, and are from $5(\mathrm{WT})$ and $8(\mathrm{Lmo} 4 \mathrm{gt} /+)$ cells $\left({ }^{*} p=0.02\right.$, Bonferroni test).

BLA to downstream neural structures including the NAc and OFC, which aid in the selection of appropriate behavioral responses (Everitt et al., 1999; Mead and Stephens, 2003). Animals with BLA lesions are unable to use first-order conditioned stimuli as secondary reinforcers for the acquisition of a novel operant response, display deficits in conditioned reinforcement, and are insensitive to the current value of the reinforcer in outcome devaluation experiments (Everitt et al., 1989; Hatfield et al., 1996; Málková et al., 1997; Baxter et al., 2000; Mead and Stephens, 2003). Further, disconnection lesions and electrophysiological studies suggest that acquisition of reinforcing value by rewardpaired cues is dependent upon projections from the BLA to the NAc and OFC (Di Ciano and Everitt, 2004; Ambroggi et al., 2008). BLA lesions also impair the ability of cocaine-paired cues to reinstate cocaine seeking without altering cocaine selfadministration (Meil and See, 1997). These studies suggest an important role for the BLA and its efferent projections in encoding the reinforcing properties of reward-paired cues rather than the primary reward itself. The molecular mechanisms in the BLA that govern this learned behavior have been relatively unexplored. Our finding that LMO4 in the BLA is required for the attribution of motivational significance to reward-paired stimuli provides an important advance in understanding these molecular mechanisms.

LMO4 can affect synaptic plasticity by modulating activity dependent gene expression and neurite outgrowth ( $\mathrm{Vu}$ et al., 2003; Kashani et al., 2006). We demonstrated previously that, within the BLA, LMO4 is present predominantly in pyramidal neurons, where it functions to negatively regulate fear learning (Maiya et al., 2012). Mice with global or BLA-specific reduction in LMO4 display enhanced contextual and cued fear conditioning. Further, Lmo4gt+ mice display increased cFos in the BLA after fear learning, suggesting a role for $\mathrm{Lmo}_{4}$ in negatively regulating the expression of genes in the BLA that are important for fear memory formation (Maiya et al., 2012). Therefore, it is intriguing that global or BLA-specific reduction in LMO4 impairs conditioned reinforcement. Studies in rats and monkeys suggest that separate populations of neurons in the BLA encode cues paired with appetitive and aversive outcomes (Paton et al., 2006; Shabel and Janak, 2009). We do not yet know whether the transcriptional targets of LMO4 are different in these subpopulations or if different transcriptional targets mediate the effect of LMO4 on these different behaviors.

How does LMO4 affect the function of BLA pyramidal neurons? Our data point to at least two potential mechanisms. First, the results of our electrophysiological experiments implicate a novel role for LMO4 in limiting the excitability of BLA principal neurons, because neurons from $L m o 4 g t /+$ mice exhibited greater membrane excitability than WT neurons. This increase in excitability was associated with a $>20 \%$ increase in membrane resistance without a change in resting membrane potential, action potential threshold potential, amplitude half-width, or AHP amplitude. There are numerous voltage-dependent and synaptic conductances that LMO4 might contribute to increased excitability of BLA principal neurons (Faber et al., 2001; Sah et al., 2003; Kröner et al., 2005). In the hippocampus, loss of LMO4 in CA3 neurons downregulates the type 2 ryanodine receptor (RyR2), thereby compromising calcium-induced calcium release and the induction of CA3-CA1 synaptic plasticity (Qin et al., 2012), whereas, in the hypothalamus, selective ablation of LMO4 
in single-minded 1 ( $\operatorname{Sim} 1)$ neurons decreases voltage-dependent calcium channels Cav2.1 and Cav2.3 and reduces neuronal excitability (Zaman et al., 2014). Such mechanisms are predicted to dampen neuronal function and therefore would not explain enhanced excitability in BLA principal neurons of $L m o 4 g t /+$ mice. It appears, therefore, that disruption of LMO4-regulated gene transcription can lead to diverse functional outcomes that are cell-type specific.

Second, our results demonstrate reduced $\operatorname{Drd} 2$ expression, D2R-mediated signaling, and dopamine-induced exctability in the BLA of $L m o 4 g t /+$ mice. A wealth of evidence points to a role for dopaminergic signaling in the BLA in cue-reward learning and the subsequent ability of reward-paired cues to guide goaldirected behaviors. Antagonism of D1Rs and D2Rs in the BLA impairs cue-induced reinstatement to cocaine seeking (Berglind et al., 2006). Infusions of selective D3R antagonists into the BLA prevent second-order conditioning and cue-induced reinstatement to nicotine seeking in rats (Khaled et al., 2014). Pharmacological disconnection procedures performed by unilateral injections of the nonselective dopamine receptor antagonist $\alpha$-flupenthixol into the BLA and the AMPA-kainate receptor antagonist LY293558 into the NAc on the contralateral side impair second-order conditioning (Di Ciano and Everitt, 2004). Further, electrophysiological studies reveal that dopamine-induced excitability of BLA projection neurons is dependent upon D1R and D2R activation (Kröner et al., 2005). Because LMO4 is a transcriptional regulator, the molecular mechanism by which it modulates conditioned reinforcement may involve changes in gene expression and our findings implicate the D2R as a transcriptional target of LMO4 in this behavior.

The signaling pathways functioning downstream of D2R in the BLA are not known. Here, we provide evidence that D2-like activation enhances phosphorylation of AKT at $\mathrm{Thr}^{308}$ in WT mice. This result is consistent with published literature using primary cultured striatal neurons, heterologous expression systems, and in vivo in the NAc (Brami-Cherrier et al., 2002; Nair and Sealfon, 2003; Mannoury la Cour et al., 2011). Importantly, our results indicate that quinpirole-induced phosphorylation of $\mathrm{Thr}^{308}$ AKT is substantially blunted in Lmo4gt/+ mice. Although quinpirole activates both $\mathrm{D} 2 \mathrm{R}$ and $\mathrm{D} 3 \mathrm{R}$ subtypes, we were unable to detect Drd3 mRNA by qPCR in the BLA of either WT or Lmo4gt/+ mice. These assays gave us a robust signal for Drd3 mRNA in the NAc, leading us to conclude that Drd 3 mRNA is not expressed or is expressed at very low levels in the BLA. Based on this evidence, we conclude that impaired D2R signaling contributes to deficits in AKT phosphorylation in Lmo4gt/+ mice. Further, electrophysiological studies revealed a striking deficit in dopamine-modulation of BLA projection neuron excitability in Lmo4-deficient mice that is likely due to reduced D2R expression and D2-mediated signaling in $\mathrm{Lmo} 4 \mathrm{gt} /+$ mice.

LMO4 could modulate $D r d 2$ expression directly by nucleating a transcription complex that activates Drd2 transcription or it could mediate its effects indirectly by modulating the expression of other transcriptional regulators of Drd2. ChIP assays are widely used to identify transcription factor binding sites on promoter elements. However, LMO4 does not bind directly to promoter elements (Heberlein et al., 2009), making it difficult to discriminate between direct versus indirect effects of LMO4 on gene expression. Whole genome approaches such as ChIP-Seq, which do not rely on sequence information to identify binding sites, may provide an alternative strategy. Finally, nongenomic effects of LMO4 might also contribute to the observed deficits in conditioned reinforcement. A recent study found that LMO4 inhibits protein tyrosine phosphatase 1B (PTP1B) in the BLA, leading to upregulation of endocannabinoid signaling (Qin et al., 2015). However, an effect of LMO4-PTP1B signaling on D2R would need to be indirect because tyrosine phosphorylation is not known to regulate $\mathrm{D} 2 \mathrm{R}$ abundance or function.

A recent study suggested that only cues that are imbued with incentive properties can activate cFos in the BLA, NAc, and OFC (Flagel et al., 2011). It is possible that knockdown of LMO4 in the BLA disrupts a transcriptional network that impairs neuronal activation in these brain regions, leading to deficits in goaldirected behavior. Future studies using whole genome approaches such as RNA-Seq to identify additional transcriptional targets of LMO4 in the BLA should be informative in this regard. Identification of these targets may not only reveal molecular mechanisms by which LMO4 functions in the BLA, but also could enable discovery of new drug targets for the treatment of psychopathologies such as addiction, in which aberrant cue-reward learning plays an important role.

\section{References}

Ambroggi F, Ishikawa A, Fields HL, Nicola SM (2008) Basolateral amygdala neurons facilitate reward-seeking behavior by exciting nucleus accumbens neurons. Neuron 59:648-661. CrossRef Medline

Baxter MG, Murray EA (2002) The amygdala and reward. Nat Rev Neurosci 3:563-573. CrossRef Medline

Baxter MG, Parker A, Lindner CC, Izquierdo AD, Murray EA (2000) Control of response selection by reinforcer value requires interaction of amygdala and orbital prefrontal cortex. J Neurosci 20:4311-4319. Medline

Beaulieu JM, Sotnikova TD, Marion S, Lefkowitz RJ, Gainetdinov RR, Caron MG (2005) An Akt/beta-arrestin 2/PP2A signaling complex mediates dopaminergic neurotransmission and behavior. Cell 122:261-273. CrossRef Medline

Beaulieu JM, Tirotta E, Sotnikova TD, Masri B, Salahpour A, Gainetdinov RR, Borrelli E, Caron MG (2007) Regulation of Akt signaling by D2 and D3 dopamine receptors in vivo. J Neurosci 27:881-885. CrossRef Medline

Beaulieu JM, Del'guidice T, Sotnikova TD, Lemasson M, Gainetdinov RR (2011) Beyond cAMP: The Regulation of Akt and GSK3 by Dopamine Receptors. Front Mol Neurosci 4:38. Medline

Berglind WJ, Case JM, Parker MP, Fuchs RA, See RE (2006) Dopamine D1 or $\mathrm{D} 2$ receptor antagonism within the basolateral amygdala differentially alters the acquisition of cocaine-cue associations necessary for cueinduced reinstatement of cocaine-seeking. Neuroscience 137:699-706. CrossRef Medline

Brami-Cherrier K, Valjent E, Garcia M, Pagès C, Hipskind RA, Caboche J (2002) Dopamine induces a PI3-kinase-independent activation of Akt in striatal neurons: a new route to cAMP response element-binding protein phosphorylation. J Neurosci 22:8911-8921. Medline

Cador M, Robbins TW, Everitt BJ (1989) Involvement of the amygdala in stimulus-reward associations: interaction with the ventral striatum. Neuroscience 30:77-86. CrossRef Medline

Di Ciano P (2008) Drug seeking under a second-order schedule of reinforcement depends on dopamine D3 receptors in the basolateral amygdala. Behav Neurosci 122:129-139. CrossRef Medline

Di Ciano P, Everitt BJ (2004) Direct interactions between the basolateral amygdala and nucleus accumbens core underlie cocaine-seeking behavior by rats. J Neurosci 24:7167-7173. CrossRef Medline

Di Ciano P, Everitt BJ (2005) Neuropsychopharmacology of drug seeking: Insights from studies with second-order schedules of drug reinforcement. Eur J Pharmacol 526:186-198. CrossRef Medline

Everitt BJ, Cador M, Robbins TW (1989) Interactions between the amygdala and ventral striatum in stimulus-reward associations: studies using a second-order schedule of sexual reinforcement. Neuroscience 30:63-75. CrossRef Medline

Everitt BJ, Parkinson JA, Olmstead MC, Arroyo M, Robledo P, Robbins TW (1999) Associative processes in addiction and reward: the role of amygdala-ventral striatal subsystems. Ann N Y Acad Sci 877:412-438. CrossRef Medline

Faber ES, Callister RJ, Sah P (2001) Morphological and electrophysiological 
properties of principal neurons in the rat lateral amygdala in vitro. J Neurophysiol 85:714-723. Medline

Flagel SB, Cameron CM, Pickup KN, Watson SJ, Akil H, Robinson TE (2011) A food predictive cue must be attributed with incentive salience for it to induce c-fos mRNA expression in cortico-striatal-thalamic brain regions. Neuroscience 196:80-96. CrossRef Medline

Hatfield T, Han JS, Conley M, Gallagher M, Holland P (1996) Neurotoxic lesions of basolateral, but not central, amygdala interfere with Pavlovian second-order conditioning and reinforcer devaluation effects. J Neurosci 16:5256-5265. Medline

Heberlein U, Tsai LT, Kapfhamer D, Lasek AW (2009) Drosophila, a genetic model system to study cocaine-related behaviors: a review with focus on LIM-only proteins. Neuropharmacology 56:97-106. CrossRef Medline

Holland PC, Gallagher M (1999) Amygdala circuitry in attentional and representational processes. Trends Cogn Sci 3:65-73. CrossRef Medline

Kashani AH, Qiu Z, Jurata L, Lee SK, Pfaff S, Goebbels S, Nave KA, Ghosh A (2006) Calcium activation of the LMO4 transcription complex and its role in the patterning of thalamocortical connections. J Neurosci 26: 8398-8408. CrossRef Medline

Khaled MA, Pushparaj A, Di Ciano P, Diaz J, Le Foll B (2014) Dopamine D3 receptors in the basolateral amygdala and the lateral habenula modulate cue-induced reinstatement of nicotine seeking. Neuropsychopharmacology 39:3049-3058. CrossRef Medline

Kröner S, Rosenkranz JA, Grace AA, Barrionuevo G (2005) Dopamine modulates excitability of basolateral amygdala neurons in vitro. J Neurophysiol 93:1598-1610. Medline

Lasek AW, Azouaou N (2010) Virus-delivered RNA interference in mouse brain to study addiction-related behaviors. Methods Mol Biol 602:283298. Medline

Lasek AW, Kapfhamer D, Kharazia V, Gesch J, Giorgetti F, Heberlein U (2010) Lmo4 in the nucleus accumbens regulates cocaine sensitivity. Genes Brain Behav 9:817-824. CrossRef Medline

LeDoux JE (2000) Emotion circuits in the brain. Annu Rev Neurosci 23: 155-184. CrossRef Medline

Maiya R, Kharazia V, Lasek AW, Heberlein U (2012) Lmo4 in the basolateral complex of the amygdala modulates fear learning. PLoS One 7:e34559. CrossRef Medline

Málková L, Gaffan D, Murray EA (1997) Excitotoxic lesions of the amygdala fail to produce impairment in visual learning for auditory secondary reinforcement but interfere with reinforcer devaluation effects in rhesus monkeys. J Neurosci 17:6011-6020. Medline

Mannoury la Cour C, Salles MJ, Pasteau V, Millan MJ (2011) Signaling pathways leading to phosphorylation of Akt and GSK-3beta by activation of cloned human and rat cerebral D(2) and D(3) receptors. Mol Pharmacol 79:91-105. CrossRef Medline

Matthews JM, Lester K, Joseph S, Curtis DJ (2013) LIM-domain-only proteins in cancer. Nat Rev Cancer 13:111-122. CrossRef Medline
Mead AN, Stephens DN (2003) Involvement of AMPA receptor GluR2 subunits in stimulus-reward learning: evidence from glutamate receptor gria2 knock-out mice. J Neurosci 23:9500-9507. Medline

Meil WM, See RE (1997) Lesions of the basolateral amygdala abolish the ability of drug associated cues to reinstate responding during withdrawal from self-administered cocaine. Behav Brain Res 87:139-148. CrossRef Medline

Nair VD, Sealfon SC (2003) Agonist-specific transactivation of phosphoinositide 3-kinase signaling pathway mediated by the dopamine D2 receptor. J Biol Chem 278:47053-47061. CrossRef Medline

Pandey NR, Zhou X, Qin Z, Zaman T, Gomez-Smith M, Keyhanian K, Anisman H, Brunel JM, Stewart AF, Chen HH (2013) The LIM domain only 4 protein is a metabolic responsive inhibitor of protein tyrosine phosphatase 1B that controls hypothalamic leptin signaling. J Neurosci 33:1264712655. CrossRef Medline

Paton JJ, Belova MA, Morrison SE, Salzman CD (2006) The primate amygdala represents the positive and negative value of visual stimuli during learning. Nature 439:865-870. CrossRef Medline

Qin Z, Zhou X, Gomez-Smith M, Pandey NR, Lee KF, Lagace DC, Béique JC, Chen HH (2012) LIM domain only 4 (LMO4) regulates calciuminduced calcium release and synaptic plasticity in the hippocampus. J Neurosci 32:4271-4283. CrossRef Medline

Qin Z, Zhou X, Pandey NR, Vecchiarelli HA, Stewart CA, Zhang X, Lagace DC, Brunel JM, Béïque JC, Stewart AF, Hill MN, Chen HH (2015) Chronic Stress induces anxiety via an amygdalar intracellular cascade that impairs endocannabinoid signaling. Neuron 85:1319-1331. CrossRef Medline

Sah P, Faber ES, Lopez De Armentia M, Power J (2003) The amygdaloid complex: anatomy and physiology. Physiol Rev 83:803-834. CrossRef Medline

Schneider CA, Rasband WS, Eliceiri KW (2012) NIH Image to ImageJ: 25 years of image analysis. Nat Methods 9:671-675. CrossRef Medline

Shabel SJ, Janak PH (2009) Substantial similarity in amygdala neuronal activity during conditioned appetitive and aversive emotional arousal. Proc Natl Acad Sci U S A 106:15031-15036. CrossRef Medline

Stuber GD, Sparta DR, Stamatakis AM, van Leeuwen WA, Hardjoprajitno JE, Cho S, Tye KM, Kempadoo KA, Zhang F, Deisseroth K, Bonci A (2011) Excitatory transmission from the amygdala to nucleus accumbens facilitates reward seeking. Nature 475:377-380. CrossRef Medline

Vu D, Marin P, Walzer C, Cathieni MM, Bianchi EN, Saïdji F, Leuba G, Bouras C, Savioz A (2003) Transcription regulator LMO4 interferes with neuritogenesis in human SH-SY5Y neuroblastoma cells. Brain Res Mol Brain Res 115:93-103. CrossRef Medline

Zaman T, Zhou X, Pandey NR, Qin Z, Keyhanian K, Wen K, Courtney RD, Stewart AF, Chen HH (2014) LMO4 is essential for paraventricular hypothalamic neuronal activity and calcium channel expression to prevent hyperphagia. J Neurosci 34:140-148. CrossRef Medline 